Arroyo Mocho Boulder Removal Project: Lawrence Livermore National Laboratory Hetch Hetchy Pump Station

L. Burkholder, T. Kato, M. Van Hattem

June 28, 2007 
This document was prepared as an account of work sponsored by an agency of the United States Government. Neither the United States Government nor the University of California nor any of their employees, makes any warranty, express or implied, or assumes any legal liability or responsibility for the accuracy, completeness, or usefulness of any information, apparatus, product, or process disclosed, or represents that its use would not infringe privately owned rights. Reference herein to any specific commercial product, process, or service by trade name, trademark, manufacturer, or otherwise, does not necessarily constitute or imply its endorsement, recommendation, or favoring by the United States Government or the University of California. The views and opinions of authors expressed herein do not necessarily state or reflect those of the United States Government or the University of California, and shall not be used for advertising or product endorsement purposes.

This work was performed under the auspices of the U.S. Department of Energy by University of California, Lawrence Livermore National Laboratory under Contract W-7405-Eng-48. 


\title{
ARROYO MOCHO BOULDER REMOVAL PROJECT: LAWRENCE LIVERMORE NATIONAL LABORATORY HETCH HETCHY PUMP STATION
}

\author{
Alameda County, California
}

USGS Mendenhall Springs 7 1/2 Minute Quadrangle

June 1, 2007

Contact Person: Thom Kato, Environmental Protection Department, Lawrence Livermore National Laboratory (925) $422-9642$ 


\section{Table of Contents}

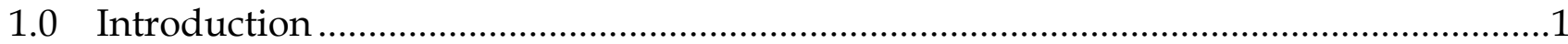

2.0 Threatened, Endangered, Proposed Threatened or Proposed Endangered Species found within the Mendenhall Springs U.S. Geological Survey 7 1/2 Minute

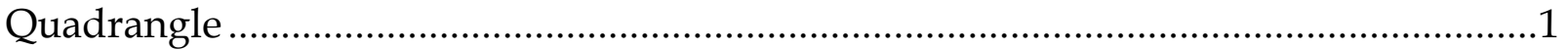

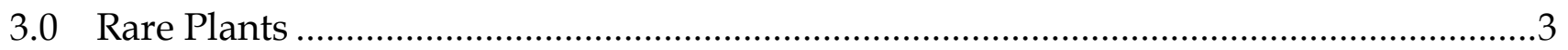

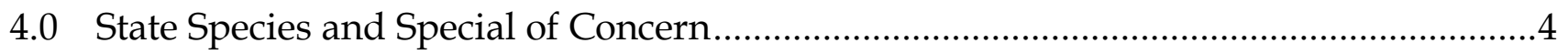

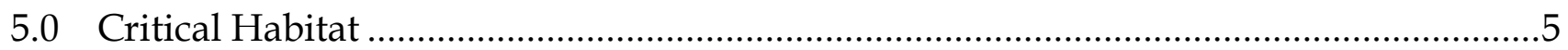

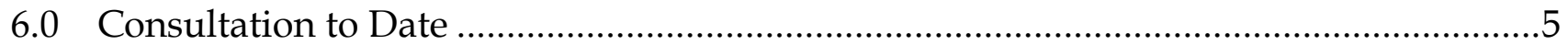

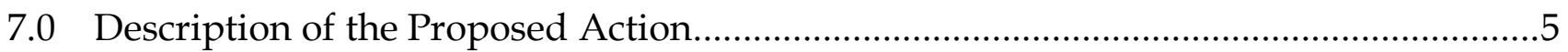

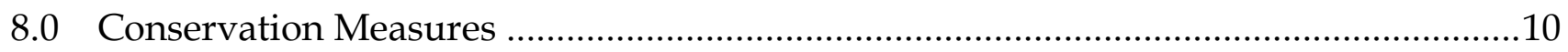

9.0 Action Area

10.0 Species with the Potential to be Impacted by the Proposed Project Species Accounts and Status of the Species in the Action Area...................................................13

11.0 Species that Occur within the Mendenhall Quad, but are Unlikely to be Affected by the Proposed Project ..............................................................................................20

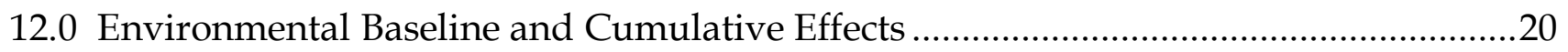

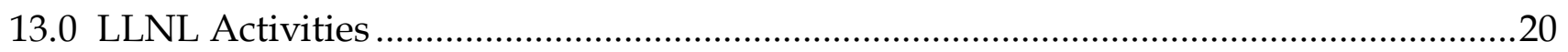

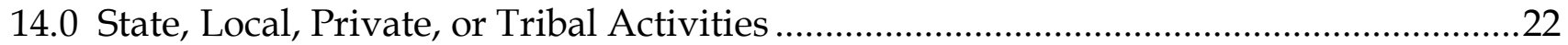

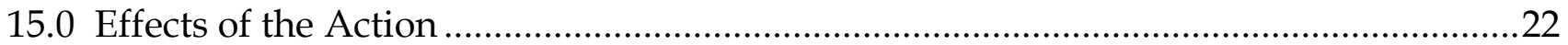

\section{Illustrations}

Figure 1 Arroyo Mocho Project Vicinity Map …............................................................

Figure 2 Arroyo Mocho Site Location Map ……............................................................

Appendix 1 Biogeographic Information and Observation System (BIOS) Query for the Arroyo Mocho Pump Station

Appendix 2 Project Area Photographs 


\subsection{Introduction}

The purpose of this biological assessment is to review the proposed Arroyo Mocho Boulder Removal Project in sufficient detail to determine to what extent the proposed action may affect any of the threatened, endangered, proposed, or sensitive species and designated or proposed critical habitats listed below. In addition, the following information is provided to comply with statutory requirements to use the best scientific and commercial information available when assessing the risks posed to listed and/or proposed species and designated and/or proposed critical habitat by proposed federal actions. This biological assessment is prepared in accordance with legal requirements set forth under regulations implementing Section 7 of the Endangered Species Act (50 CFR 402; 16 U.S.C 1536 (c)). It is our desire for the Arroyo Mocho Boulder Removal Project to receive incidental take coverage for listed species and critical habitat within the greater project area by means of amending the previous formal Section 7 consultation (1-1-04-F-0086) conducted a few hundred meters downstream by Lawrence Livermore National Laboratory (LLNL) in 2002. All conservation measures, terms and conditions, and reporting requirements from the previous Biological Opinion (1-1-04-F-0086) have been adopted for this Biological Assessment and/or amendment.

\subsection{Threatened, Endangered, Proposed Threatened or Proposed Endangered Species found within the Mendenhall Springs U.S. Geological Survey 7 1/2 Minute Quadrangle}

The species and critical habitat listed below were considered in this biological assessment based on lists provided by the U.S. Fish and Wildlife Service (USFWS, 2007). In addition, California Department of Fish and Game databases were queried and reviewed including the Biogeographic Information and Observation System (BIOS; BIOS, 2007), the California Natural Diversity Database (CNDDB), and CalFish (Appendix 1).

\section{Invertebrates}

- Branchinecta lynchi

Vernal pool fairy shrimp (Threatened)

Species Excluded from this Analysis:

Suitable habitat for the vernal pool fairy shrimp does not exist in the project area or along its access route. Due to the lack of suitable habitat, this species is excluded from this biological assessment.

- $\quad$ Euphydryas editha bayensis

Bay Checkerspot Butterfly (Threatened)

Species Excluded from this Analysis:

Serpentine outcrops and soils do exist within the Arroyo Mocho watershed; however, the current distribution of this species does not extend east (USFWS, 1998) far enough to consider the Bay Checkerspot Butterfly in this biological assessment. Furthermore, serpentine soils do not exist in the impact area (i.e., stream bottom) or the worker access route (see project 
description for explanation). Similarly, appropriate host plants (Platego erecta, Castilleja densiflora or C. exserta) do not occur within the impact area.

Fish

- Onchorhyncus mykiss

Central California Coastal Steelhead (Threatened) (NOAA)

Species Excluded from this Analysis:

During consultation for the Arroyo Mocho Road Improvement and Fish Passage Project (1-1-04-F-0086), the National Oceanic and Atmospheric Administration (NOAA) concluded that the anadromous form of O. mykiss did not currently occur at the project area and consultation was not required (NOAA, 2004). For this project, potential affects on Central California Coastal Steelhead will be considered in a separate consultation with NOAA Fisheries.

\section{Amphibians}

- Rana aurora draytonii

California red-legged frog (Threatened)

- Ambystoma californiense

California tiger salamander (Threatened)

\section{Reptiles}

- $\quad$ Masticophis lateralis euryxanthus

Alameda whipsnake (Threatened) (State Threatened)

Critical Habitat

\section{Birds}

- $\quad$ Haliaeetus leucocephalus

Bald Eagle (Threatened) (State Endangered, State Fully Protected)

Species Excluded from this Analysis:

A breeding pair of Bald Eagles occurs at the Del Valle Reservoir west of the project area. The project as proposed will not affect the pair of eagles; nor does the project area provide any resources used by Bald Eagles.

\section{Mammals}

- Vulpes macrotis mutica

San Joaquin kit fox (Endangered)

Species Excluded from this Analysis:

Suitable habitat for the San Joaquin kit fox is lacking from the project area.

Steep-walled canyons, oak woodlands and interspersed patches of sage scrub habitat characterize the project area and are not normally associated with the habitat preferences of the San Joaquin kit fox. Therefore, the San Joaquin kit Fox will not be considered in this biological assessment. 


\subsection{Rare Plants}

Rare plant surveys of the project site and potential access routes were conducted on April 20, 2007, May 10, 2007, and May 25, 2007. No plants listed under the federal or California endangered species acts or the California Native Plant Protection Act were observed during these surveys (Lisa Paterson, pers. comm.).

- Amsinckia grandiflora

Large-flowered fiddleneck (Endangered)

Species Excluded from this Analysis:

Suitable habitat for the large-flowered fiddleneck is lacking in the project area. It is found primarily in open grassland areas, such as those suitable for grazing, and in woodlands. The project area is characterized by coastal sage scrub and steep-walled canyons, and has no extended grassland. Minute oak woodland habitat and small grassy patches near the project site were surveyed for occurrence of the large-flowered fiddleneck and none were found. The large-flowered fiddleneck will not be considered in this biological assessment.

- Arctostaphylos pallida

Pallid manzanita or Alameda or Oakland Hills manzanita (Threatened) Species Excluded from this Analysis:

Although the project area is within the range and elevation of this species, the habitat of the project area is predominantly not suitable for its occurrence. It is also found in Arctostaphylos dominated chaparral, whereas the project area is characterized by coastal sage scrub dominated by Artemisia california and riparian woodlands. Very few populations exist (only 13), and are located in mesic conditions or in maritime chaparral, on north and east facing slopes. In contrast, the project area is predominantly dry-mesic to xeric coastal sage scrub and riparian woodland. Pallid manzanita is unlikely to occur in the project area and will not be considered in this biological assessment.

\section{- $\quad$ Clarkia franciscana}

Presidio clarkia (Endangered)

Species Excluded from this Analysis:

Presidio clarkia is has an extremely limited distribution. Only five populations are known: two in the Presidio in San Francisco, and three within 0.5 miles of each other in the Oakland Hills of Alameda County. Existing populations only occur on serpentine substrate in coastal prairie grassland communities. While serpentine substrate does exist near the project area, it is relatively far from existing populations of this species, in Alameda. Furthermore, the study area is not coastal and is a canyon with steep walls and little open grassland. Presidio clarkia is very unlikely to occur in the project area and will no be considered in this biological assessment. 
- $\quad$ Cordylanthus palmatus

Palmate-bracted bird's-beak (Endangered)

Species Excluded from this Analysis:

Palmate bracted bird's-beak grows on seasonally-flooded, saline-alkali soils in lowland plains and basins at elevations of less than 500 feet. There are no saline-alkali soils at the project area, which is characterized as a dry-mesic to xeric canyon. Wet areas at the project area are riparian, in contrast to the seasonally inundated basins or plains in which this species occurs. The elevation of the project area is also substantially higher than the distribution of palmate-bracted bird's-beak. This species is not considered in this biological assessment.

- $\quad$ Lasthenia conjugens

Contra Costa goldfields (Endangered)

Species Excluded from this Analysis:

Suitable habitat for Contra Costa goldfields does not occur in the project area. This species occurs in vernal pools within open grassy areas in woodlands and valley grasslands from sea level to 1,500 feet. The project area does not include vernal pool habitat and is therefore entirely unsuitable. Grassy areas are very small, dry, and are surrounded by coastal sage scrub and oak woodland. Contra Costa goldfields is not considered in this biological assessment.

\subsection{State Species and Special of Concern}

The following species are not afforded protection under the Federal Endangered Species Act. However, they are declining throughout their range in California (Jennings and Hayes, 1994) and will be considered in this biological assessment because they are present in Arroyo Mocho and the project area. Furthermore, the Department of Energy (DOE)/National Nuclear Security Administration (NNSA; hereafter DOE/NNSA) recognizes its role as an environmental stewards and will continue to assist both federal and state resource agencies with conservation of declining species and habitats.

- Rana boylii

Foothill yellow-legged frog (Species of Special Concern)

- $\quad$ Clemmys marmorata

Western pond turtle (Species of Special Concern)

- Masticophis flagellum ruddocki

San Joaquin coachwhip (Species of Special Concern) 


\subsection{Critical Habitat}

The action addressed within this biological assessment falls within Critical Habitat for the Alameda whipsnake.

\subsection{Consultation to Date}

As a federal agency the DOE/NNSA has a history of Section 7 consultation with the USFWS regarding projects at the Livermore Site and Site 300, the two properties that constitute LLNL. The Arroyo Mocho pump station is owned by the City of San Francisco but operated and maintained by LLNL. The Arroyo Mocho Pump Station draws water from the Hetch Hetchy water system and has been the primary water source for LLNL's Livermore Site and Sandia National Laboratory since the 1960's. LLNL is also responsible for maintenance of the access road, which has the LLNL's Livermore Site and Sandia National Laboratories water line buried in it.

In 2003, DOE/NNSA formally consulted (1-1-04-F-0086) with the USFWS and NOAA over potential impacts to threatened and endangered species as a result of removing a concrete seasonal crossing on Arroyo Mocho downstream of the pump station. The concrete crossing was determined to be unsafe for maintenance personnel accessing the pump station and was the uppermost barrier for anadromous fish migration in Arroyo Mocho. Therefore, LLNL replaced the barrier with a bridge, removed aggraded cobble/gravel, and constructed a series of weirs to stabilize the streambed and avoid head cutting. The Arroyo Mocho Road Improvement and Anadromous Fish Passage Project was a success, and the streambed has stabilized and is no longer a fish barrier.

DOE/NNSA has not discussed the current project as proposed with the Sacramento USFWS. Therefore, consultation history on this project is limited to this biological assessment.

\subsection{Description of the Proposed Action}

\section{Project Proponent}

Ray Chin, Mechanical Utilities Group Leader

Lawrence Livermore National Laboratory

P.O. Box 808, L-604

Livermore, CA. 94551 


\section{Action Agency}

Michael Brown, Assistant Manager

Environmental Stewardship Division

U.S. Department of Energy

National Nuclear Security Administration

Livermore Site Office

P.O. Box 808, L-293

7000 East Avenue

Livermore, CA. 94551

\section{Project Description}

At the project site, the steep canyon walls of Arroyo Mocho are actively eroding (north side) resulting in periodic release of large boulders into the active channel of Arroyo Mocho. These boulders re-direct stream flow, especially during high flow events. Currently, two boulders that measure approximately 5 -feet by 8-feet are directing seasonal high flows into the gabion retaining wall (south side) and concrete footing at the base of the slope supporting the pump station (Appendix 2). According to LLNL's consulting geotechnical firm, high flows directed into the gabion wall could threaten the integrity of the overall structure and put the pump station at risk. Failure of the pump station would have catastrophic effects on the stream and surrounding habitat, and eliminate the primary water source for LLNL's Livermore Site and Sandia National Laboratory.

\section{Project Location}

Arroyo Mocho is an important tributary within the Alameda Creek watershed (Figure 1). Arroyo Mocho is approximately 10 miles long and drains into Arroyo de la Laguna at River Mile (RM) 7. Arroyo de la Laguna enters Alameda Creek at RM 17. The Arroyo Mocho pump station is located in the lower end of the Arroyo Mocho canyon before Arroyo Mocho flows onto the Livermore plain in Livermore (Figure 2). 


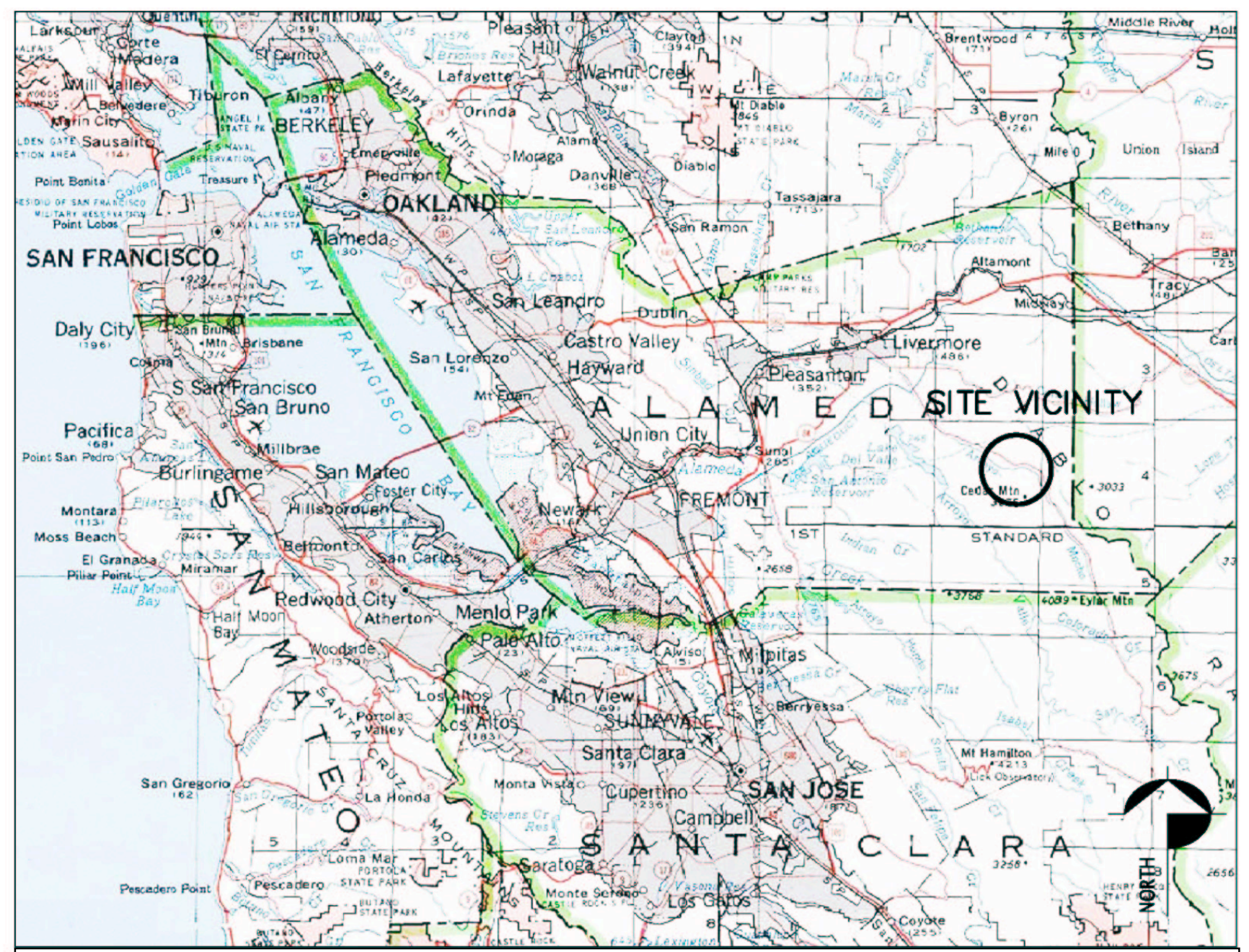

Figure 1. Arroyo Mocho is located in the Diablo Range, southeast of Livermore. Arroyo Mocho is an important tributary to Alameda Creek, an anadromous fish-bearing stream. 


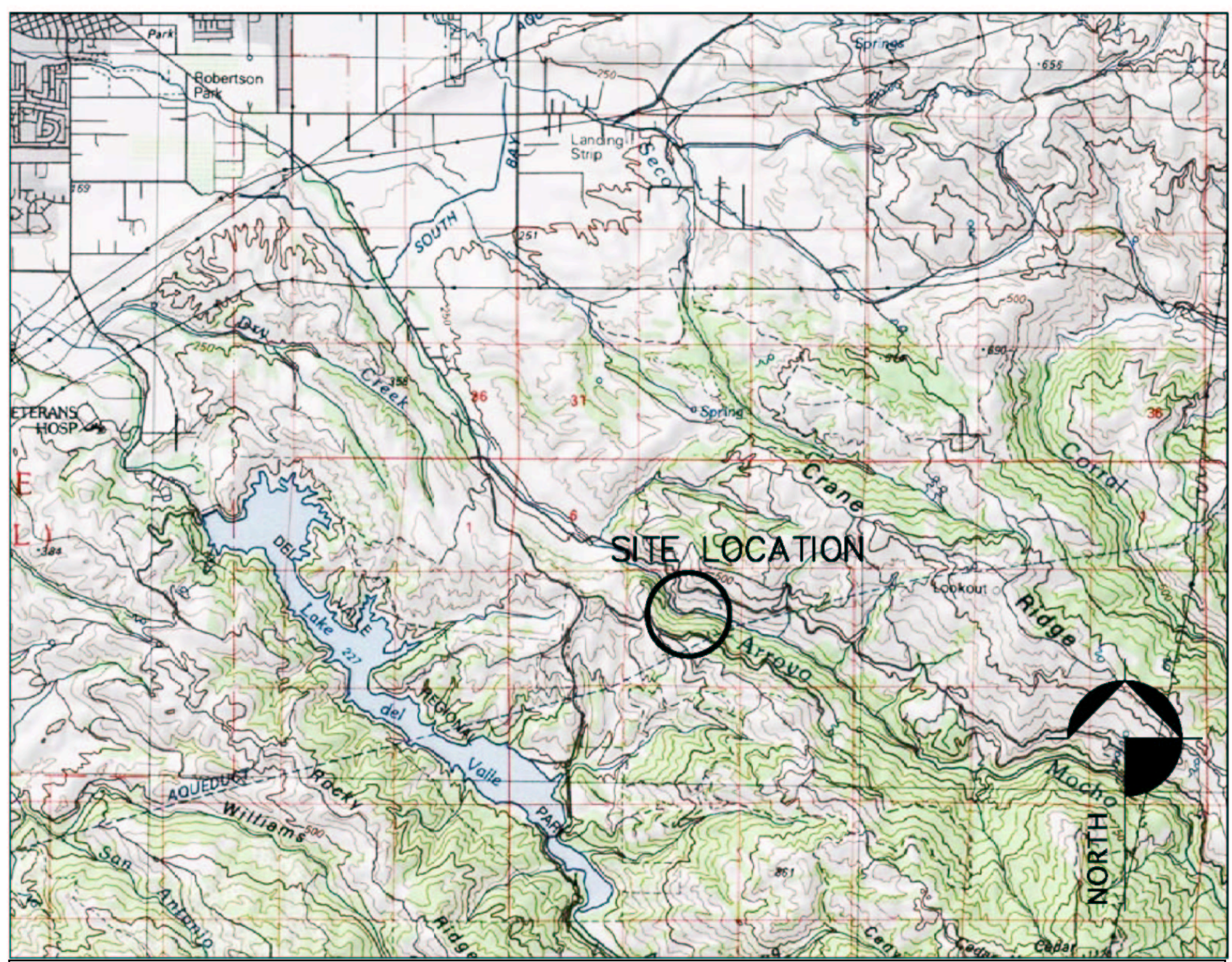

Figure 2. The Arroyo Mocho Boulder Removal Project Site is located southeast of the City of Livermore in the USGS Mendenhall Springs 7 1/2 Minute Quadrangle. 


\section{Project Timing}

The project as proposed would be for ongoing maintenance beginning in 2007 and extending to subsequent years if additional boulders fall into the stream channel and redirect flow into the retaining wall. In any given year, work would occur between August 15 and October 15. Activities below the Arroyo Mocho Pump Station (i.e., pump station apron) are limited to the period after the nesting season is complete in order to protect an active Cliff Swallow (Petrochelidon pyrrhonota) colony.

\section{Project Methods}

The objective of the project is to breakup the boulders into manageable pieces that can be moved manually (i.e., by hand) to the edge of the active channel. The disaggregated rock will be placed strategically at the edge of the stream channel to provide additional rock slope protection. To avoid creating a fish barrier, if boulders proposed for removal are embedded in the stream channel, a qualified fluvial geomorphologist must first examine the effects of their removal on stream morphology.

Prior to boulder demolition, the immediate work area will be isolated from the stream flow if needed. No work will occur in flowing water. Minor, localized streambed modification may be done by hand using sand bags to deflect flows, or create a cofferdam if needed. If necessary, PVC pipe will be used to convey flows from the cofferdam to the reach downstream of the project area. At no time will flows be disrupted to the point of termination. Heavy-duty poly sheeting may also be incorporated into the coffer damn to help deflect flows around the work area. At the conclusion of the project, all imported materials will be removed from the streambed and disposed of properly.

Hydraulic splitting is the demolition method proposed to disaggregate the boulders shown in Appendix 2, Photos 4-5. The boulders will be broken by first drilling 13/4-inch diameter holes in the rock to a depth to be determined in the field. The hand-held drill will either be electric or a gas powered rotary hammer drill. Once the holes are drilled, the hydraulic splitters (e.g., cylinder) will be inserted into the holes and the splitters will be connected to the pump. The pump will either be electric, pneumatic, or gas powered. A complete system consists of a cylinder, 30 feet of high and low pressure hoses, high and low pressure whips, quick connect couplings, a hydraulic pump, and lubricant. While the exact make and model of the hydraulic splitting unit is yet to be determined, information on hydraulic splitting can be viewed on the Internet at http://www.elco.com/splitter.htm. No modification to upland habitat, vegetation removal, or the existing infrastructure is proposed. A crew of three or four individuals from LLNL's Labor Shop will do the work. The total project footprint centered on the two boulders is approximately 25 -feet by 25 -feet. The process of splitting the boulders and moving the boulder fragments by hand is expected to take approximately 3 to 5 days, depending on the number of boulders present in any given year.

LLNL has evaluated other options for moving (e.g., large crane) or breaking the boulders with chemicals (e.g., Betonamit $\left.{ }^{\circledR}\right)$. The use of heavy equipment operated from the pump station could potentially hoist the boulders out of the active channel accomplishing the objectives of the project. However, logistically this option appears to be too challenging to implement and also has the potential of degrading habitat below the pump station 
consisting mostly of California sage brush (Artemesia californica). Betonamit ${ }^{\circledR}$ is a calciumoxide based, non-explosive rock cracking agent that is an alternative to jack hammering, hydraulic splitting, or explosive approaches for breaking apart large boulders. While Betonamit ${ }^{\circledR}$ is an option and has been reported to be nontoxic, the chemical is caustic and could potentially change stream water chemistry (Campbell and Foster, 2006). Betonamit ${ }^{\circledR}$ would require extreme care to reduce the potential of releasing the dried chemical in the project area (i.e., streambed). Because of the obvious concern for the Arroyo Mocho, this option does not represent the best available option. Furthermore, when compared to hydraulic rock splitting, the duration of the project will be greatly extended because of the overnight curing requirement.

\section{Conclusion and Rationale for the Project}

Hydraulic rock splitting represents the best option for this project because the pump can be operated from beyond the stream margin, the system will generate less noise than other options (i.e., blasting), chemicals aren't required, and in general the hydraulic splitting option will generate little to no vibration. Furthermore, this option should be relatively quick, allowing for rapid mobilization and completion compared with other options. We estimate that from start to finish in any given year, the project will take approximately one week.

As stated in the project description, the steep canyon walls of Arroyo Mocho are actively eroding (north side) resulting in periodic release of large boulders into the active channel of Arroyo Mocho. These boulders re-direct flow, especially during high flow events. As a result, two boulders that measure approximately 5 -feet by 8 -feet are currently directing seasonal high flows into the gabion retaining wall (south side) and concrete footing at the base of the slope supporting the pump station (Appendix 2). High flows directed into and over the gabion wall could threaten the integrity of the overall gabion structure and put the pump station at risk. Failure of the pump station would have catastrophic effects on the stream and surrounding habitat, and eliminate the primary water source for LLNL's Livermore Site and Sandia National Laboratory.

\section{Other Interrelated and Interdependent Actions}

LLNL is unaware of any other actions proposed within or related to the project as proposed. LLNL is currently investigating other slope instability issues along the access road and at the pump station. It is likely that LLNL, with the assistance of consultants with geotechnical expertise, will continue to investigate the Arroyo Mocho watershed at and around the pump station to develop a management plan that keeps the pump station operational in perpetuity.

\subsection{Conservation Measures}

The following conservation measures are intended to reduce or eliminate harm, harassment, injury, or death of Alameda whipsnakes, California red-legged frogs, and California tiger salamanders and are similar to those implemented in the 2004 Biological Opinion (1-1-04-F-0086): 
1) A qualified biologist (s) will conduct all biological surveys, monitoring and mitigation activities. The biologist (s) will be experienced in their respective field of specialization, and have permits as required to perform the required work.

2) Within five days prior to de-watering and/or other construction related activity, all size classes of foothill yellow-legged frogs and western pond turtles will be moved out of the work area to a suitable pool situated upstream or downstream of the project area. The biologist (s) will determine the best and closest location to safely translocate individuals out of harm's way.

3) A qualified biologist (s) will conduct pre-construction surveys for any sensitive species, such as foothill yellow-legged frog, western pond turtle, California red-legged frog, California tiger salamander, and Alameda whipsnake.

4) A qualified biologist (s) will conduct a pre-construction survey to identify all aquatic life and stream conditions prior to construction. Fish protection measures may include exclusions of fish from the project area, fish passage through or around the worksite, and/or fish removal from the project area.

5) In-channel construction (which includes work below the average high water line on the stream banks) is confined to the summer low-precipitation period of June 1 through October 15. In addition, in-channel work will only commence after the qualified biologist (s) visually survey the project area for special status species.

6) A qualified biologist (s) will monitor the in-channel activities, in-stream habitat, and performance of sediment control/detention devices for the purpose of identifying and reconciling any condition that could adversely affect aquatic life. Daily construction activities will not begin until a qualified biologist (s) has surveyed the entire project site including the lay-down and equipment storage areas. If the qualified biologist (s) identifies a condition that could adversely affect aquatic life or lead to the take of a listed species, they will notify the on-site construction manager and halt the work until the situation is remedied.

7) Prior to the start of construction, a worker education program will be presented at the project site or in a classroom setting by a qualified biologist (s). All personnel must sign and date their program, keep a copy of the education program on-site and submit a signed form to document the training they received. The education program will include a description of each special status species and its habitat, the general provisions of the Act, the necessity of adhering to the Act, measures implemented to avoid species impacts, and the work boundaries of the project.

8) Permanent seeding, vegetation and mulching will be considered for all aspects of the proposed action when suitable. 
9) Erosion control blankets will be installed on all exposed slopes.

10) Fiber rolls (straw roll/coir logs) will be installed along the project boundary in areas where substantial rainfall run-on could enter the site from upslope and off-site areas that could result in erosion and sediment problems. These rolls will be used to shorten slope length and slow run-off and at grade breaks where slopes transition to a steeper slope.

11) All equipment will be fitted with the appropriate noise dampening equipment such as mufflers and baffles.

12) A spill management kit will be on site for all aspects of the project. Workers will be educated on spill containment and appropriate methodologies; all equipment will be thoroughly investigated for leaks prior to use, and a spill response plan including important state and federal contacts, will be in place and on site prior to any in stream work.

13) Erosion Control Best Management Practices (BMPs) or other materials used on the project site contain nylon mesh or grids capable of capturing and holding snakes. The qualified biologist will ensure that no materials at the project site will capture or harm snakes.

\subsection{Action Area}

The action area is limited to the estimated 25 -foot by 25 -foot project footprint centered on the two boulders. Workers will also need to hike down to the project area from the pump station, so the route they select will be in addition to the action area. Traversing the south slope can easily be done without causing any ground disturbance. Human activity at or near the pump station occurs as LLNL staff conducts maintenance and monitoring daily. Conversely, human activity downslope in the streambed is much less common and in itself is a form of disturbance.

Furthermore, operation of hand tools required for drilling the boulders as well as setting up and operating the hydraulic splitter will generate noise. The pneumatic pump required for the hydraulic rock splitter system is 3 horsepower $(\mathrm{hp})$ and is rated at $86-90$ decibels $(\mathrm{dB})$. The drill and hydraulic splitter will be operated from the same pump. Noise generated from the project will be intermittent and will be loudest during the drilling portions of the project. Additionally, noise generated from the associated power tools will be localized (i.e., muffled) by the steep canyon walls.

In the event that instream diversion or modification is needed, placing sandbags within the streambed will mobilize some sediment. However, sediment transport will be temporary and will be limited to sediment already naturally occurring in the streambed. Since the 2007 wet season was well below normal, it is likely that the project areas will already be dry by late summer when the project is scheduled to occur.

See Appendix 2 for photographs of the action area. 


\subsection{Species with the Potential to be Impacted by the Proposed Project Species Accounts and Status of the Species in the Action Area}

\section{California red-legged frog (Rana aurora draytonii)}

\section{Status}

In June of 1996, the California red-legged frog (Rana aurora draytonii) was listed as threatened under the federal Endangered Species Act (USFWS, 1996). Critical habitat was designated for the California red-legged frog in March of 2001 although most has been rescinded due to a recent court decision (USFWS, 2002a).

\section{Status in the Action Area}

Prior to the 2004 Arroyo Mocho Road Improvement and Anadromous Fish Passage Project (1-1-04-F-0086) a number of surveys were completed, four of which were done specifically to detect California red-legged frogs and followed the USFWS Interim Guidance; and several others targeting foothill yellow-legged frogs, specifically oviposition sites. All surveys were conducted by Michael van Hattem (LLNL wildlife biologist from 1999-2005), and Lisa Paterson or Jim Woollett (current LLNL wildlife biologists). With the exception of one California red-legged frog detected at the base of the pump station, surveys had failed to detect California red-legged frogs. During the course of the surveys, we also discovered a degraded Ranid frog that we suspected was a California red-legged frog, however, it was fairly decomposed and conclusive identification was difficult.

The study area for historical surveys was 0.5 miles downstream of the low-flow crossing to 0.5 miles upstream of the crossing, which included the reach containing the pump station. While implementing mitigation measures for the project, we discovered approximately 15 sub-adult and adult California red-legged frogs. Based on surveys and implementation of conservation measures associated with the previous Arroyo Mocho Project (1-1-04-F-0086), we conclude that California red-legged frogs seasonally occupy Arroyo Mocho during the summer and fall months. The source population for the frog migration is unknown, but the ridge west of project areas is active ranch land and probably has stock ponds. Through all of our survey work we have never detected California red-legged frog breeding (i.e., egg masses or larvae) in Arroyo Mocho. Arroyo Mocho is likely an important oversummering location for California red-legged frogs in the Arroyo Mocho watershed.

The CNDDB (2006) reports California red-legged frogs locations from the Arroyo Mocho Road Improvement and Anadromous Fish Passage Project (1-1-04-F-0086; Appendix 1).

\section{Threats in the Project Area}

During one of the historic surveys, a single adult bullfrog (Rana catesbeiana) was discovered in a large scour pool that formed below the low-flow crossing. The bullfrog was dispatched during the survey. It is likely that bullfrogs are doing similar movements as California red-legged frogs and may eventually be more common in Arroyo Mocho (at least seasonally). A significant bullfrog population exists in the Del Valle reservoir as well as downstream of the reservoir in Arroyo Del Valle. 
Cattle are allowed to graze in sections of Arroyo Mocho; the effects of cattle grazing are most pronounced on the presence of mulefat (Baccharis salicifolia) and may positively or negatively affect native Ranids, depending on intensity, in the upper portion of Arroyo Mocho. Development of large homes along Mines Road continues to fragment habitat as well as increase other stressors associated with urbanization (i.e., traffic, pets, non-native species, etc.).

\section{Distribution, Habitat, Life History}

The current range of the California red-legged frog includes Pacific slope drainages from Napa and Sonoma Counties to Baja California, Mexico (USFWS, 2002b). Isolated populations are also found in the Sierra Nevada foothills north of Sacramento (USFWS, 2002b). Historically, the California red-legged frog was known to occur in 46 counties, but now has been extirpated from at least 24 of these (USFWS, 1996).

The California red-legged frog is found in a variety of aquatic, riparian and upland habitats in areas below 1,500 meters elevation. Aquatic systems used by California red-legged frogs include dune swales, ephemeral ponds, intermittent streams, seasonal wetlands, springs, seeps, permanent ponds, perennial creeks, and man-made ponds (USFWS, 2002b). In their critical habitat designation for the California red-legged frog, the USFWS (2001) describes the California red-legged frog as potentially using virtually any aquatic system that is in close proximity to some permanent water source.

California red-legged frog habitat use can change as environmental conditions fluctuate. California red-legged frogs can complete their entire life cycle in one pond or utilize a mosaic of habitat types (USFWS, 2001). Where available, California red-legged frogs spend a considerable amount of time within riparian vegetation. In grazed areas, adult California red-legged frogs often are observed hundreds of feet from breeding ponds, presumably foraging, seeking appropriate microhabitats or dispersing (van Hattem pers. obs.).

California red-legged frogs often use California ground squirrel burrows, deep desiccation cracks, or woody vegetation as thermal refuge during both dry and cold periods of the year.

Breeding adults are frequently associated with relatively deep ( $>2$ feet) slow moving water in areas of dense riparian vegetation, although breeding frogs are found in areas without dense emergent or riparian vegetation in water depths less than 2 feet (USFWS, 2001; USFWS, 2002b). The breeding period for California red-legged frogs is from late November to late April although most frogs lay their eggs in March (Jennings and Hayes, 1994; USFWS, 2002b). Based on focused oviposition surveys in Livermore California, LLNL biologists have determined that the majority of California red-legged frogs breed between February 15 and March 15. Emergent vegetation, twigs and roots are typically used for oviposition sites. Eggs develop into larvae in 20 to 22 days. Although over wintering tadpoles have been observed in some areas, tadpoles typically develop into frogs in 11 to 20 weeks (USFWS, 2002b).

During periods of wet weather, California red-legged frogs can make movements over upland habitats to other aquatic habitats. During dry periods, California red-legged frogs can disperse from breeding habitat to forage or to seek summer habitat in response to 
declining water levels. A radio-tagged California red-legged frog in the Guadalupe Dunes of California central coast was observed to move approximately 1.75 miles through upland and aquatic habitats over the course of a wet season (Rathbun and Schneider, 2001). The California red-legged frog recovery plan (USFWS, 2002b) describes unpublished research by Bulger conducted in Santa Cruz County. In this study, California red-legged frogs were observed to travel distances of 0.25 mile to 2 miles without regard to topography, vegetation type, or riparian corridors.

\section{Alameda whipsnake (Masticophis lateralis euryxanthus)}

\section{Status}

The Alameda whipsnake was listed as Threatened under the Federal Endangered Species Act in 1997 and Threatened in the state of California in 1971 (CDFG, 2003). The main threats to the Alameda whipsnake are habitat alteration (loss of chaparral and coastal sage scrub) and fire suppression (which allows vegetation to overgrow its preferred open habitat). Habitat fragmentation has led to isolation of populations (USFWS, 2003). The project area is within designated critical habitat for the Alameda whipsnake.

\section{Status in the Action Area}

No surveys have occurred within the project area. It is assumed that Alameda whipsnakes are present in the sage scrub and oak woodland community adjacent to the project area. No Alameda whipsnakes are reported by the CNDDB (2007) within a three-mile radius of the project area but that most likely reflects a lack of surveys rather than a void in species presence (Appendix 1).

\section{Threats in the Project Area}

Development of large homes along Mines Road continues to fragment habitat as well as increase other stressors associated with urbanization (i.e., traffic, pets, non-native species, etc.).

\section{Distribution, Habitat, Life History}

Alameda whipsnakes are found in the inner coast range in western and central Contra Costa and Alameda counties (USFWS, 2003). Alameda whipsnake are found in chaparral, sage scrub, northern coyote brush scrub and riparian scrub (Swaim, 2002). They also use grasslands and oak woodlands adjacent to scrub habitats (Swaim, 1994). Rocky outcrops appear to be important to the whipsnake as a source of cover and increased density of prey items (lizards) (Swaim, 1994; Stebbins, 1985).

Alameda whipsnake is a slender, fast moving snake with a narrow neck and a relatively broad head with large eyes (Swaim, 2002). Its dorsal side is sooty black, with yelloworange dorsal-lateral stripes. The anterior portion of the underside is orange to rufus (Swaim, 2002). Adult snakes reach up to five feet in length (Swaim, 2002). Alameda whipsnakes are active during the day, in the spring and summer. In the winter and early spring (November - March), they often remain in a hibernaculum (shelter), although they may be active for short periods of time (USFWS, 2003). Mating occurs in late March through mid-June. Little is known about oviposition sites. Alameda whipsnakes feed 
primarily on western fence lizards (Sceloporus occidentalis). They also feed on skinks, frogs, snakes, and birds (USFWS, 2003).

\section{California tiger salamander (Ambystoma californiense)}

\section{Status}

The Central population of the California tiger salamander is listed as Threatened by the USFWS (2004). The most important threat to California tiger salamander populations is habitat loss and fragmentation (Holland et al., 1990), especially due to urban expansion and conversion of aquatic and upland habitat to agriculture (USFWS, 2000). Additional significant population threats include predation by introduced species such as fish (Shaffer et al., 1993) and bullfrogs (Shaffer et al., 1993), vehicle-related mortality during breeding migrations (Gibbs, 1998), and rodent control programs (Loredo et al., 1996).

\section{Status in the Action Area}

The high gradient lotic habitat of Arroyo Mocho is not suitable breeding habitat for the California tiger salamander. California ground squirrel (Spermophilus beecheyi) burrows are also lacking from the project area. California tiger salamanders are known to occur within two miles of the project area (CNDDB, 2007) in the stock ponds east of the Del Valle reservoir.

\section{Threats in the Project Area}

Development of large homes along Mines Road continues to fragment habitat as well as increase other stressors associated with urbanization (i.e., traffic, pets, non-native species, etc.).

\section{Distribution, Habitat, Life History}

The California tiger salamander is found in the Central Valley and adjacent foothills and coastal grasslands of California (Loredo and van Vuren, 1996). The range of this California endemic extends from Sonoma County and the Colusa-Yolo County border in the north, continuing south through the Central Valley and the Coast Range to Santa Barbara and Tulare counties (Shaffer et al., 1993; Jennings and Hayes, 1994). Alameda and Contra Costa County are among the remaining regions that support the greatest concentration of California tiger salamanders (Shaffer et al., 1993).

California tiger salamanders inhabit grasslands and open woodlands with available small mammal burrows and breeding sites (Jennings and Hayes, 1994) in areas with a Mediterranean climate of cool wet winters and hot dry summers (Loredo and van Vuren, 1996). California tiger salamanders breed in temporary rain pools and permanent waters of grasslands and open woodland of low hills and valleys. Breeding sites can include both natural (vernal pools) and artificial (stock ponds) lentic environments. California tiger salamanders spend much of the year underground, in the burrows of ground squirrels, pocket gophers (Thomys bottae), and badgers (Taxidea taxus). California tiger salamanders emerge for only brief periods to breed typically after the first rains of the year in November or December (Jennings and Hayes, 1994; Loredo and van Vuren, 1996) and can continue through April (Petranka, 1998). 
The larval period lasts from three to six months (Petranka, 1998) and, because of this, California tiger salamanders require breeding pools to remain hydrated for at least this length of time. Metamorphosis of salamander larvae begins in late spring or early summer and is followed by the dispersal of metamorphs from their natal ponds into terrestrial habitat (Holland et al., 1990; Loredo et al., 1996).

Trenham (2001) recorded adult California tiger salamanders using burrows up to 248 meters from release points adjacent to breeding pools, and juvenile salamanders have been reported to use burrows up to $1.2 \mathrm{~km}$ from breeding sites (Jennings and Hayes, 1994).

\section{State Species of Special Concern}

\section{Foothill yellow-legged frog (Rana boylii)}

\section{Status}

The foothill yellow-legged frog has been extirpated from most historic locations in southern California and throughout much of the foothills in the Sierra Nevada (Jennings and Hayes, 1994). The California Department of Fish and Game lists the foothill yellowlegged frog as a Species of Special Concern, and the species is a federal Species of Concern.

\section{Status in the Action Area}

Foothill yellow-legged frogs are relatively common within the 1-mile stretch of Arroyo Mocho historically surveyed, including the stream reach at the pump station.

\section{Threats in the Project Area}

Development of large homes along Mines Road continues to fragment habitat as well as increase other stressors associated with urbanization (i.e., traffic, pets, non-native species, etc.).

\section{Distribution, Habitat, Life History}

The foothill yellow-legged frog is a moderate-sized (1.5-3.4 inches) frog that inhabits the Coast Range from the Oregon border to San Luis Obispo County and the western foothills of the Sierra Nevada in California. It lays egg masses during the spring in small- to medium-sized streams and rivers with cobble-sized or greater substrate, a significant amount of riffle habitat, and partial shade (Jennings and Hayes, 1994; Kupferberg, 1996). Arroyo Mocho oviposition sites are also gravel dominated. Females lay single clutches of greater than 1000 eggs usually in the same general locations each year, often at a stream confluence or in other microhabitats where boulders create below average flow (Kupferberg, 1996). Tadpoles are cryptically colored and difficult to observe in a flowing stream environment. Metamorphosis occurs between July and September. At some locations near breeding sites, metamorphs (post-metamorphic juveniles) can be observed relatively easily in late summer and early fall along stream banks. Bullfrogs and predatory, introduced fishes negatively affect tadpoles (Jennings and Hayes, 1994; Kupferberg, 1996). 


\section{Western pond turtle (Clemmys marmorata)}

\section{Status}

The western pond turtle has been separated into two subspecies (C. m. marmorata is the northwestern subspecies and C. m. pallida is the southwestern subspecies), both of which are listed as Species of Special Concern by the CDFG. Western pond turtle is also a federal Species of Concern.

\section{Status in Action Area}

Western pond turtles occur within the 1-mile stretch of Arroyo Mocho historically surveyed for this project. Turtles within Arroyo Mocho appear to be associated with slowwater pools; none have been observed within riffles or runs.

\section{Threats in the Project Area}

Development of large homes along Mines Road continues to fragment habitat as well as increase other stressors associated with urbanization (i.e., traffic, pets, non-native species, etc.).

\section{Distribution, Habitat, Life History}

The western pond turtle originally inhabited many of the Pacific drainage basins in California. It ranges from western Washington to northern Baja California, mostly west of the Sierra Nevada-Cascade crest (Stebbins, 1985). The western pond turtle ranges in size to just over 8 inches $(21 \mathrm{~cm})$ with a low carapace that is generally olive, brownish or blackish (Stebbins, 1985; Jennings and Hayes, 1994). It primarily inhabits permanent water sources including ponds, streams, and rivers. It is often seen basking on logs, mud banks, or mats of vegetation. Although it is an aquatic species with webbed feet, it will move overland in response to fluctuating water levels, an apparent adaptation to the variable rainfall and unpredictable flows that occur in many coastal California drainage basins (Rathbun et al., 1992). In addition, it can over-winter on land or in water or remain active in the winter, depending on environmental conditions (Rathbun et al., 1992; Jennings and Hayes, 1994).

Females travel from aquatic sites into open, grassy areas to lay eggs in a shallow nest (Holland, 1992; Rathbun et al., 1992). Nests have been reported from 2-400 meters or more away from water bodies (Jenning and Hayes, 1994). It appears that most hatchlings overwinter in the nest (Holland, 1992; Jennings and Hayes, 1994), and placing nests away from watercourses makes young less susceptible to death by flood events that commonly occur during the winter weather period (Rathbun et al., 1992). Additional explanations for placing nests away from watercourses include avoidance of predators such as raccoon (Procyon lotor) and sex determination, which may be affected by temperature (Rathbun $e t$ al., 1992). Pond turtles may live for 40 years or more (Jennings and Hayes, 1994), and are therefore sometimes found in degraded areas with little or no available nesting habitat. Adults sometimes persist for several years in poor aquatic habitat without any successful recruitment, presumably due to introduced predators or unsuitable conditions for egg deposition. 


\section{San Joaquin coachwhip (Masticophis flagellum ruddocki)}

\section{Status}

The San Joaquin coachwhip is a State Species of Special Concern and a Federal Species of Concern (CDFG, 2003). The main threats to the San Joaquin coachwhip are habitat alteration and associated loss of mammalian prey items and their burrows (which are used for refuge). Habitat loss includes conversion of grassland or scrub to agriculture in the San Joaquin Valley, and urban development in the inner Coast Ranges (Jennings and Hayes, 1994).

\section{Status in Action Area}

No surveys have occurred within the project area, but similar to the Alameda Whipsnake, suitable habitat for the San Jouaquin coachwhip is abundant; therefore, the project area is considered occupied.

\section{Threats in the Project Area}

Development of large homes along Mines Road continues to fragment habitat as well as increase other stressors associated with urbanization (i.e., traffic, pets, non-native species, etc.).

\section{Distribution, Habitat, Life History}

San Joaquin coachwhip are found from Colusa County in the Sacramento Valley southward to the Kern County portion of the San Joaquin Valley and westward into the inner South Coast Ranges, from 20 meters to around 900 meters above sea level (Jennings and Hayes, 1994).

San Joaquin coachwhip utilize open, dry, vegetation with little or no tree cover (Morafka and Banta, 1976). In the western San Joaquin Valley, it occurs in valley grassland and saltbush scrub associations (Jennings and Hayes, 1994; Montanucci, 1965; Banta and Morafka, 1968; Sullivan, 1981). The San Joaquin coachwhip is generally found in areas with mammal burrows, which it uses for refuge during cold weather and for egg-laying sites (see below).

Little is known about the San Joaquin coachwhip. They are active during the day, generally only when air temperature is above $80^{\circ} \mathrm{F}\left(28^{\circ} \mathrm{C}\right)$ (Jennings and Hayes, 1994). When temperatures are low, such as at night, they remain below the surface in small mammal burrows. Generally, the snakes remain in burrows all winter and begin to emerge in April or May. Adults may retreat to burrows for overwintering as early as the first part of August (Jennings and Hayes, 1994). Mating is thought to occur in May, and egg laying is thought to occur in June or early July. Oviposition sites have not been found, but are probably located in rodent burrows. Clutch size probably ranges from 4 to 20 (Jennings and Hayes 1994; Stebbins, 1985). Food items include lizards and small birds and mammals, and possibly carrion (Jennings and Hayes, 1994). Blunt- nosed leopard lizards, western whiptails, side-blotched lizards, and San Joaquin antelope ground squirrels are known prey (Jennings and Hayes, 1994; Montanucci, 1965). 


\subsection{Species that Occur within the Mendenhall Quad, but are Unlikely to be Affected by the Proposed Project}

- Branchinecta lynchi

Vernal pool fairy shrimp (Threatened)

Suitable habitat for the vernal pool fairy shrimp does not exist in the project area or along it's access route. Due to the lack of suitable habitat, this species is excluded from this biological assessment.

- $\quad$ Euphydryas editha bayensis

Bay Checkerspot Butterfly (Threatened)

Serpentine outcrops and soils do exist within the Arroyo Mocho watershed; however the current distribution of this species does not extend east (USFWS, 1998) far enough to consider the Bay Checkerspot Butterfly in this biological assessment. Furthermore, serpentine soils do not exist in the impact area (i.e., stream bottom) or the worker access route (see project description for explanation). Similarly, appropriate host plants (Platego erecta, Castilleja densiflora or C. exserta) do not occur within the impact area.

- $\quad$ Haliaeetus leucocephalus

Bald Eagle (Threatened) (State Endangered, State Fully Protected) A breeding pair of Bald Eagles occurs at the Del Valle Reservoir west of the project area. The project as proposed will not affect the pair of eagles; nor does the project area provide any resources used by Bald Eagles.

\subsection{Environmental Baseline and Cumulative Effects}

\subsection{LLNL Activities}

LLNL has completed the following projects intended to reduce erosion or slope failure at the Arroyo Mocho Pump Station. LLNL activities at Arroyo Mocho have positively affected Arroyo Mocho through erosion reduction, planting of native vegetation, and removal of a known barrier to steelhead migration.

\section{1) Arroyo Mocho Pump Station Access Road Repairs:}

The upper portion of the access road (approximately 150 feet) has been repaired with the addition of 20 yards of "Class 2" road base. This was done to address the erosion that has occurred over the last few years. No waste was generated and no soil or rock were deposited in the streambed. The intent of the project was to assure safe road passage to the pump station.

\section{2) Arroyo Mocho Pump Station Grading and Drainage:}

Within the developed footprint of the fenced facility, the Arroyo Mocho Pump Station pad is being modified to divert all rain and Fire Protection test water from running off and over the pump station pad and apron. This work includes saw cutting and removing 
approximately 300 square feet of asphalt, and installing a shallow concrete " $\mathrm{V}$ " ditch (5 yards of concrete) that channels all the water to an existing catch basin that diverts the water to the streambed. Approximately 6 yards of new asphalt are being placed to divert rain and Fire Protection test water to this new drainage swale. All the old asphalt has been removed and returned to the LLNL site for proper disposal. No soil or rock have been or will be deposited in the streambed. This project was completed to protect the existing pump pad and retaining wall from further erosion due to water flowing over the pad and then onto the apron possibly contributing to the "settling" of the pump station.

\section{3) Mocho Access Road Tree and Scrub Planting:}

Approximately 400 feet of roadside ( 5 and 15 feet off the road) was planted with native trees and scrubs. LLNL's botanist was consulted on which species to plant and the appropriate season for planting. All waste that is generated will be disposed of properly and no soil or rock will be deposited in the streambed. The intent of the project is to stabilize current and potential slides to prevent mobilization of soil and rock. Depending on the success of planting, additional planting may occur.

\section{4) Culvert Extension:}

Culverts from existing roadside catch basins will be extended down to Arroyo Mocho to prevent hillslope erosion. Seven roadside catch basins are currently located along the access road, several of which have created gully erosion features. The end of each culvert will be designed to reduce further erosion.

\section{5) Pile installation:}

In 2000, steel piles were driven into a section of the Arroyo Mocho access road. The piles are intended to prevent a mass-wasting event in which the access road would be lost.

\section{6) Inclinometers Installation:}

Inclinometers were installed at the pump station to monitor movement.

\section{7) Crack Monitors:}

Crack monitors have been installed on the "wing" walls at the Mocho Pump Station Pad to track existing cracks in the wall.

\section{8) Hydro-seeding:}

The entire length of the access road was hydro-seeded with Pyramat ${ }^{\circledR}$ and seed mix to reduce active erosion along the road cut.

\section{9) Apron Voids:}

Erosion from improperly installed culverts caused erosion alongside the pump station resulting in undermining of the concrete apron. In 2004, these voids were grouted and the culverts were lengthened to prevent additional erosion. 


\subsection{State, Local, Private, or Tribal Activities}

State, local, private, or tribal activities in the action area are unknown. The upper portion of Arroyo Mocho continues to be developed into low density-large homes and ranches. The lower portion of the watershed also continues to be developed; ranching remains a common land use, and vineyards are present throughout the area. As a consequence of development within the greater Tri-Valley area, traffic along Mines Road is increasing which increases fragmentation of the landscape and increased road mortality of wildlife, including threatened and endangered species.

\subsection{Effects of the Action}

The Arroyo Mocho Boulder Removal Project may affect the California red-legged frog, California tiger salamander, and Alameda whipsnake, but will not adversely affect these species or Alameda whipsnake Critical Habitat. It is our determination that disaggregating and relocating chunks of boulders to the stream margin in the manner described in the Project Description, with the Conservation Measures in place as described, will have discountable affects on the California red-legged frog, California tiger salamander, and the Alameda whipsnake. Our findings are based on the temporal nature of the project, the alternatives analyzed, and ultimately the methods determined (hydraulic splitting) to have the lowest overall impact on Arroyo Mocho and sensitive species found within this portion of the Arroyo Mocho watershed. 


\section{Literature Cited}

Banta, B. H., and D. J. Morafka. 1968. An annotated checklist of the recent amphibians and reptiles of the Pinnacles National Monument and Bear Valley, San Benito and Monterey counties, California, with some ecological observations. The Wasmann Journal of Biology 26(2): 161-183.8

Biogeographic Information and Observation System (BIOS). 2007. California Department of Fish and Game database queried on 10 April 2007 at http://bios.dfg.ca.gov/.

California Department of Fish and Game. 2003. State and federally listed endangered and threatened animals of California. Available online at: http://www.dfg.ca.gov/hcpb/species/t_e_spp/tespp.shtml

California Natural Diversity Database (CNDDB). 2007. California Department of Fish and Game database queried on 10 April 2007 at http://bios.dfg.ca.gov/.

Campbell, C. G., and C. Foster. 2006. Evaluation of the potential for water chemistry adjustment with exposure to Betonamit ${ }^{\circledR}$ Non-explosive rock cracking agent. Lawrence Livermore National Laboratory UCRL-TR-229239

Gibbs, J. P. 1998. Amphibian movement in response to forest edges, roads, and streambeds in southern New England. J Wildl Manage 65:584-589.

Holland, D.C., M.P. Hayes and E. McMillan. 1990. Late summer movements and mass mortality in the California tiger salamander (Ambystoma californiense). Southwest Naturalist 35:217-220.

Holland, D.C. 1992. A synopsis of the distribution and current status of the western pond turtle in (Clemmys marmorata) Oregon. Report prepared for Nongame Division Oregon Department of Fish and Wildlife

Jennings, M. R., and M. P. Hayes. 1994. Amphibians and Reptile Species of Special Concern in California. California Department of Fish and Game, 255 pp.

Kupferberg, S. J. 1996. Hydrologic and geomorphic factors affecting conservation of a river-breeding frog (Rana boylii). Ecological Applications, Vol. 6(4).

Loredo, I. D. and D. van Vuren. 1996. Reproductive ecology of a population of the California tiger salamander. Copeia 4: 895-901.

Loredo, I., D. van Vuren and M.L. Morrison. 1996. Habitat use and migration behavior of the California tiger salamander. J Herpet 30(2): 282-285.

Montanucci, R. R. 1965. Observations on the San Joaquin leopard lizard, Crotaphytus wislizenii silus Stejneger. Herpetologica 21(4): 270-283.

Morafka, D. J., and B. H. Banta. 1976. Ecological relationships of the recent herpetofauna of Pinnacles National Monument, Monterey and San Benito Counties, California. The Wasmann Journal of Biology 34(2): 304-324.

National Oceanic and Atmospheric Administration (NOAA). 2004. Concurrence letter from Rodney McInnis to Colonel McCormick and Lily Sanchez concerning the 
Arroyo Mocho Road Improvement and Fish Passage Project (March 11, 2004 151422SWR04SR9182:GRS).

Petranka, J.W. 1998. Salamanders of the United States and Canada. Smithsonian Intuition. $587 \mathrm{pp}$.

Rathbun, G.B., N. Siepel, and D. Holland. 1992. Nesting behavior and movements of western pond turtles (Clemmys marmorata). The Southwestern Naturalist, Vol. 37, No. 3, September.

Rathbun, G. B. and J. Schneider. 2001. Translocation of California red-legged frogs (Rana aurora draytonii). Wildl Soc Bull 29(4): 1300-1303.

Shaffer, H. B., R.N. Fisher, and S.E. Stanley. 1993. Status report; The California tiger salamander (Ambystoma californiense). Final report for the California Department of Fish and Games. 36pp. Plus figures and tables.

Stebbins, R. C. 1985 . A field guide to western reptiles and amphibians. 2nd ed., revised. Houghton Mifflin, Boston. 336 pp.

Sullivan, B. K. 1981. Distribution and relative abundance of snakes along a transect in California. Journal of Herpetology 15(2): 247-248.

Swaim, K. 1994. Aspects of the ecology of the Alameda whipsnake (Masticophis lateralis euryxanthus). Masters Thesis, California State University, Hayward, CA. 140 pp.

Swaim, K. 2002. Results of baseline (pre burn) trapping survey for the Alameda whipsnake (Masticophis lateralis euryxanthus) at Lawrence Livermore National Laboratories S300, Alameda and San Joaquin, California. Draft report. Prepared for Lawrence Livermore National Laboratory by Swaim Consulting. Nov. 2002. 16 pp.

Trenham, P.C. 2001. Terrestrial habitat use by adult California tiger salamanders. J. Herpetol. 35:343-346.

U. S. Fish and Wildlife Service. 1996. Endangered and Threatened Wildlife and Plants; Determination of Threatened Status for the California red-legged frog; Final Rule. Federal Register 61(101) 25813-25833.

U. S. Fish and Wildlife Service (USFWS). 1998. Recovery Plan for Serpentine Soil Species of the San Francisco Bay Area. Portland, Oregon 330+ pp.

U.S. Fish and Wildlife Service. 2000. Endangered and threatened wildlife and plants; listing the Santa Barbara County distinct population segment of the California Tiger Salamander as Endangered; Final Rule. Federal Register 65(184)57242-57264.

U.S. Fish and Wildlife Service. 2001. Final determination of critical habitat for the California red-legged frog. Federal Register 66(49) 14626-14758.

U. S. Fish and Wildlife Service. 2002a. Sacramento Fish and Wildlife Office California redlegged frog recovery. < http://sacramento.fws.gov/es/herps/crf.htm> Accessed 2002 Dec 30

U. S. Fish and Wildlife Service. 2002b. Recovery plan for the California red-legged frog (Rana aurora draytonii). Region 1, U. S. Fish and Wildlife Service Portland, Oregon. 
U.S. Fish and Wildlife Service. 2003. Alameda whipsnake (Masticophis lateralis euryxanthus). Species account. Prepared by Endangered Species Div., Sacramento Fish \& Wildlife Office, U.S. Fish \& Wildlife Service. Available online at: http://sacramento.fws.gov/es/animal_spp_acct/alameda_whipsnake.htm

U.S. Fish and Wildlife Service. 2003. Western spadefoot toad (Spea hammondii). Species account. Prepared by the Endangered Species Division, Sacramento Fish and Wildlife office, U.S. Fish and Wildlife Service. Available online at: http://sacramento.fws.gov/es/animal_spp_acct/w_spadefoot_toad.htm

U.S. Fish and Wildlife Service. 2003a. Endangered and threatened wildlife and plants; listing of the central California distinct population segment of the California tiger salamander; proposed rule. Federal Register 68(100) 28648-28670.

U. S. Fish and Wildlife Service (USFWS). 2004. Endangered and Threatened Wildlife and Plants; Determination of Threatened Status for the California Tiger Salamander; and Special Rule Exemption for Existing Routine Ranching Activities; Final Rule. 50 CFR Part 17: 47212-47248.

U. S. Fish and Wildlife Service (USFWS). 2007. Endangered Species Division: Species list for the Arroyo Mocho Boulder Removal Project. List (070410124521) generated online at http://www.fws.gov/sacramento/es/spp_lists/auto_letter.cfm on April 10, 2007.

\section{Personal Observation}

van Hattem, M. 2002, Wildlife Biologist, Lawrence Livermore National Laboratory, Livermore, California.

\section{Personal Communication}

Paterson, L. 2007, Wildlife Biologist, Lawrence Livermore National Laboratory, Livermore, California.

\section{List of Contacts/Contributors}

Michael van Hattem, SHN Consulting Engineers and Geologists, Inc. (SHN). Eureka, CA. mvanhattem@shn-engr.com 707-441-8855 
Appendix 1 Biogeographic Information and Observation System (BIOS) Query for the Arroyo Mocho Pump Station 


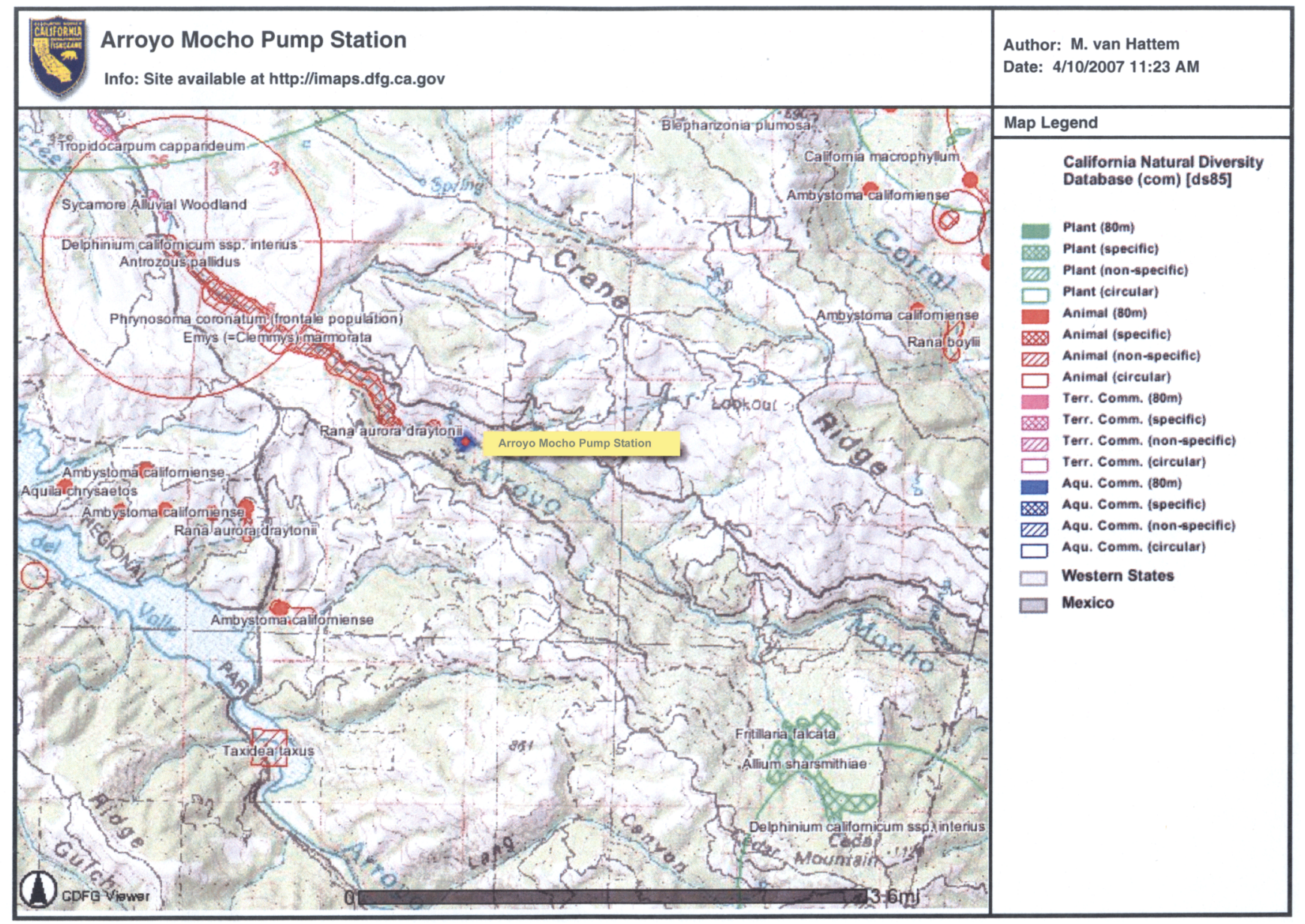

A Biogeographic Information and Observation System (BIOS) query was completed that shows the various locations of reported species of special concern; California Native Plant Society listed species, as well as state and federal threatened and endangered species. California red-legged frog locations shown immediately downstream of the project area were reported to the California Natural Diversity Database (CNDDB) as a result of LLNL's last project at Arroyo Mocho: the Arroyo Mocho Road Improvement and Fish Passage Project (1-104-F-0086). Location and numbers of foothills-yellow legged frog and western pond turtle associated with the previous project were also submitted to the CNDDB but do not currently show on the database. 
Appendix 2 


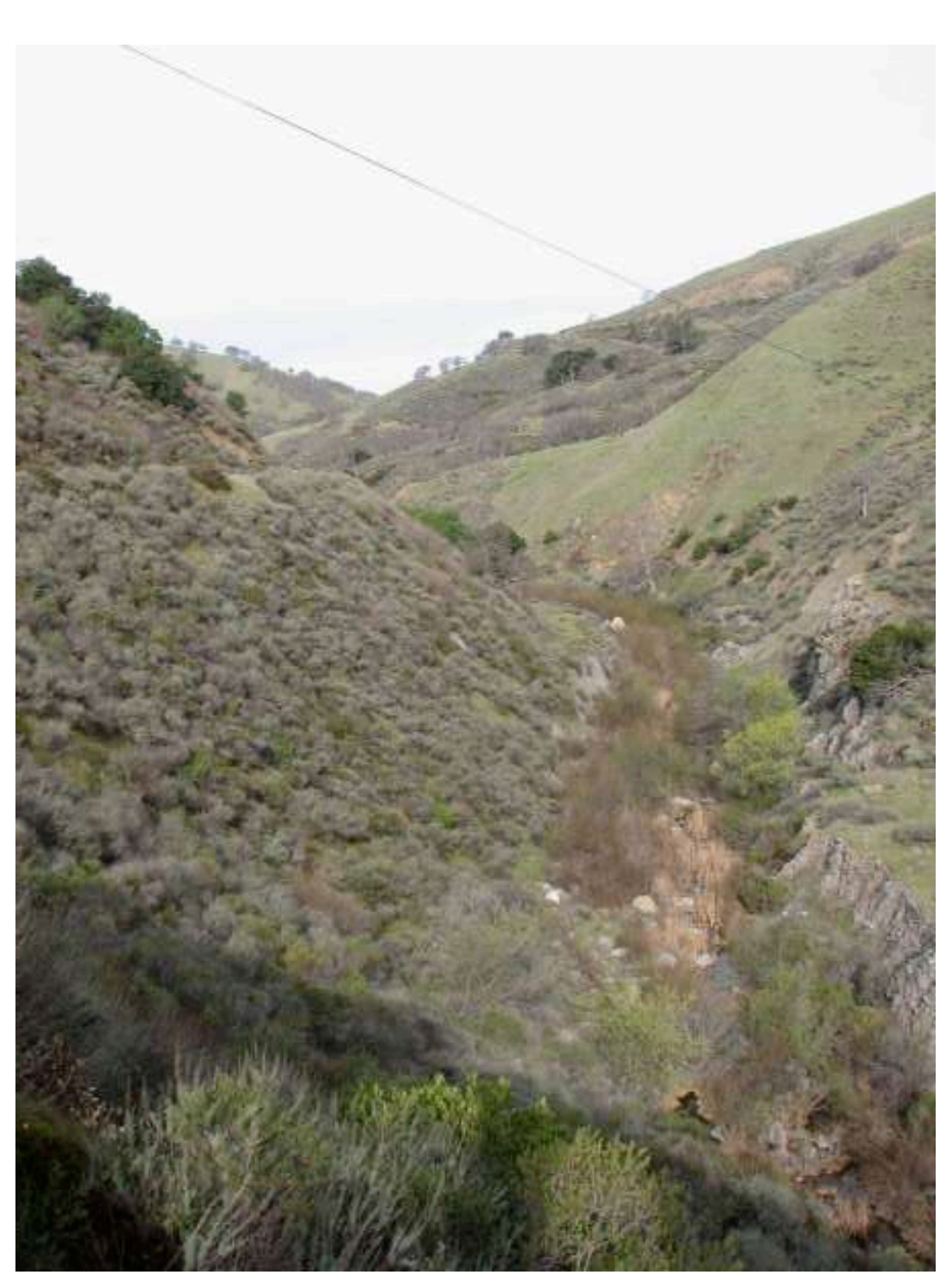

Photo 1. Steep slopes and a medium to high gradient stream course characterize Arroyo Mocho, downstream of the pump station. The streambed includes angular cobble and boulders and to a lesser extent gravel and sand. A relict terrace of excavation spoils can be seen in the photo on the right bank and then on the left bank. The stream has cut through the spoils and stabilized at its current elevation.

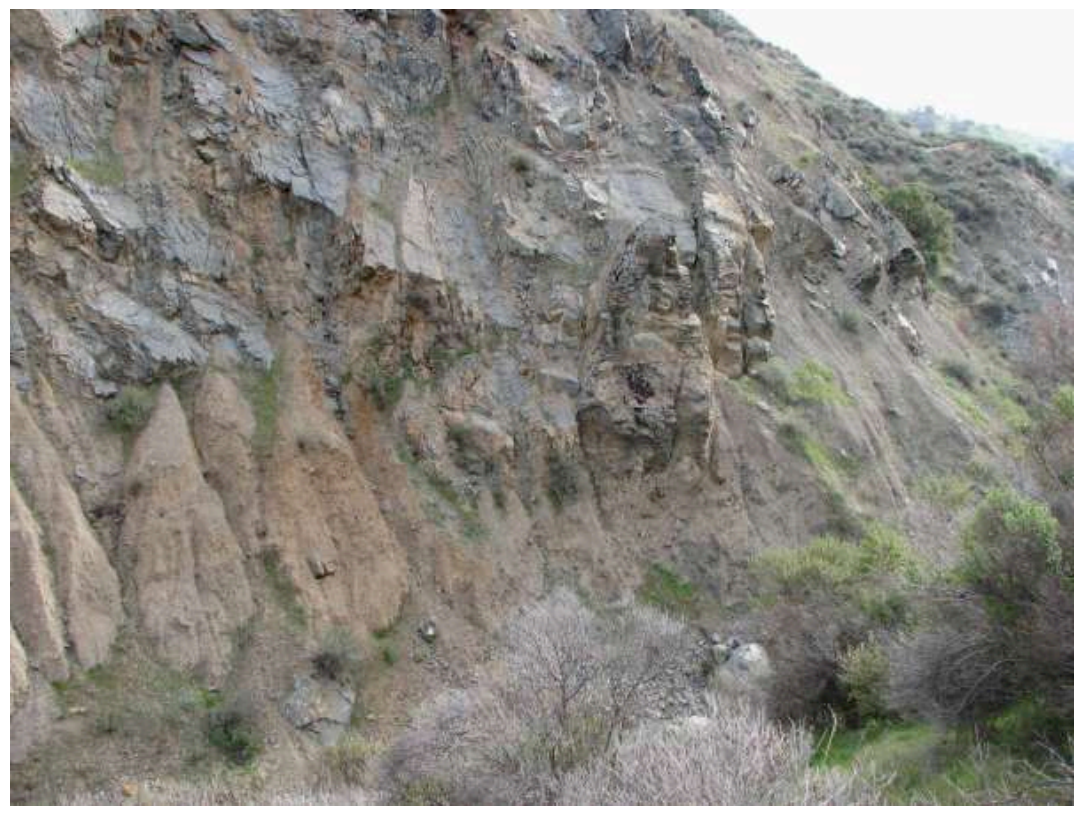

Photo 2. The north bank of Arroyo Mocho at the pump station is a steep, 100-200 foot slope that is actively eroding and periodically releases large boulders into Arroyo Mocho. This photo was taken from the concrete apron of the Arroyo Mocho pump station on April 27, 2007. 


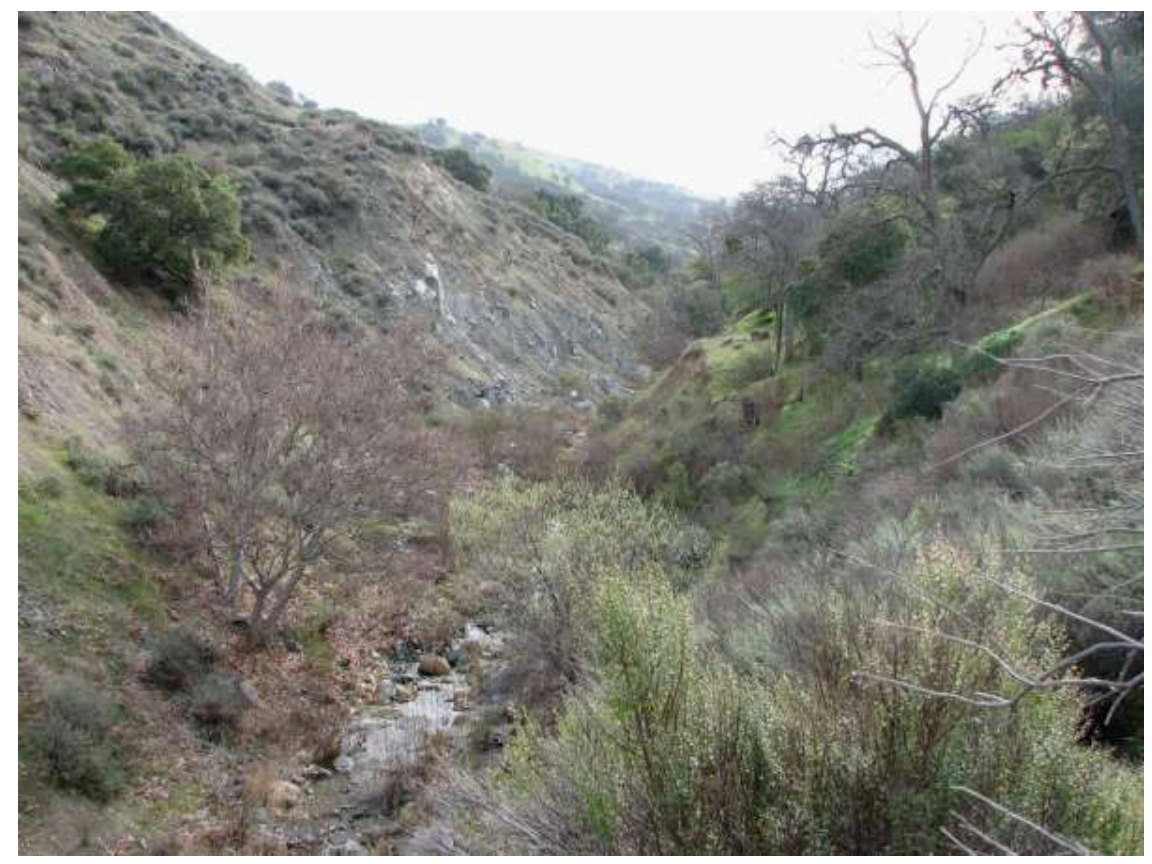

Photo 3. Arroyo Mocho upstream of the pump station has streambed morphology similar to below the pump station; however, it doesn't contain a spoils terrace. Similar to the project area in Photo 2, the north/right bank of Arroyo Mocho is also actively eroding as shown in this photo.

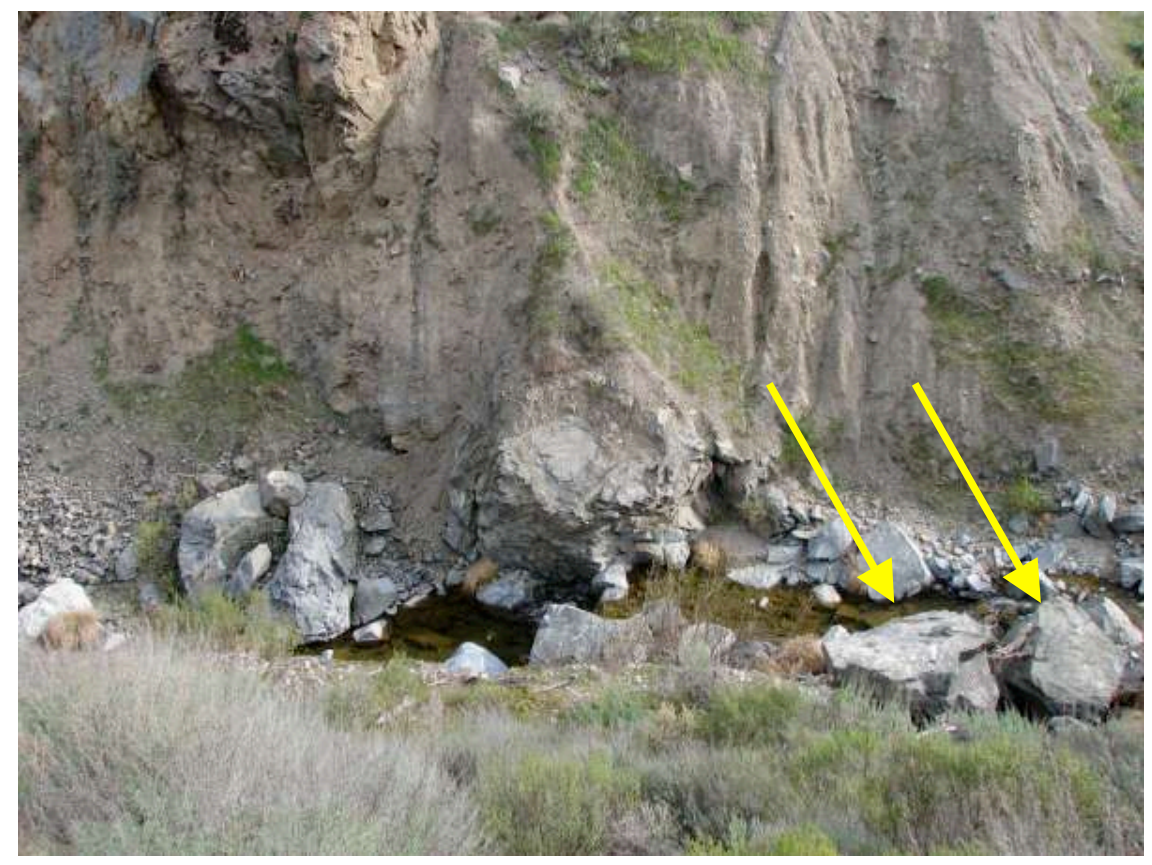

Photo 4 . The intent of the project is to disaggregate the two boulders (yellow arrows) and relocate the fragments out of the active flow path of Arroyo Mocho. During high flow events, water is deflected by the boulders into and on top of the gabion wall that protects the toe of the slope that supports the pump station. Immediately below the two target boulders is the narrowest point on Arroyo Mocho and the gabion wall. Photo was taken from the pump station apron on April 27, 2007. 


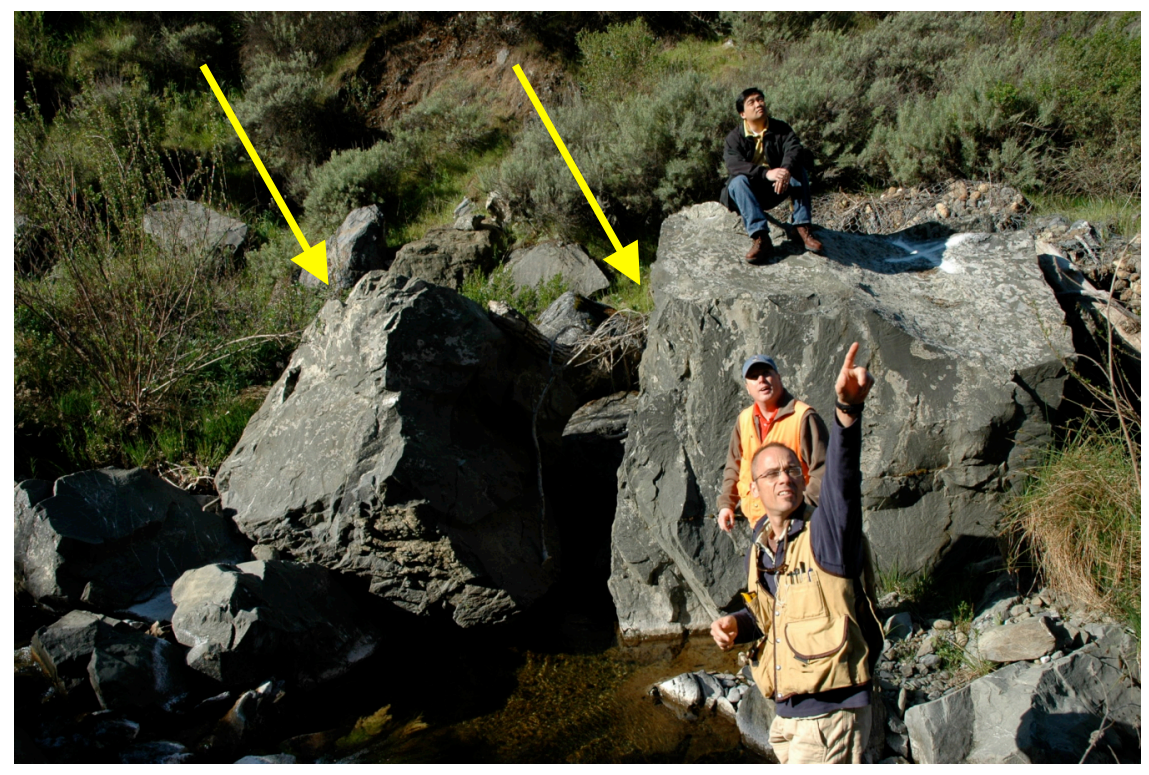

Photo 5. The two boulders (yellow arrows) are shown with engineer and geologists for scale.

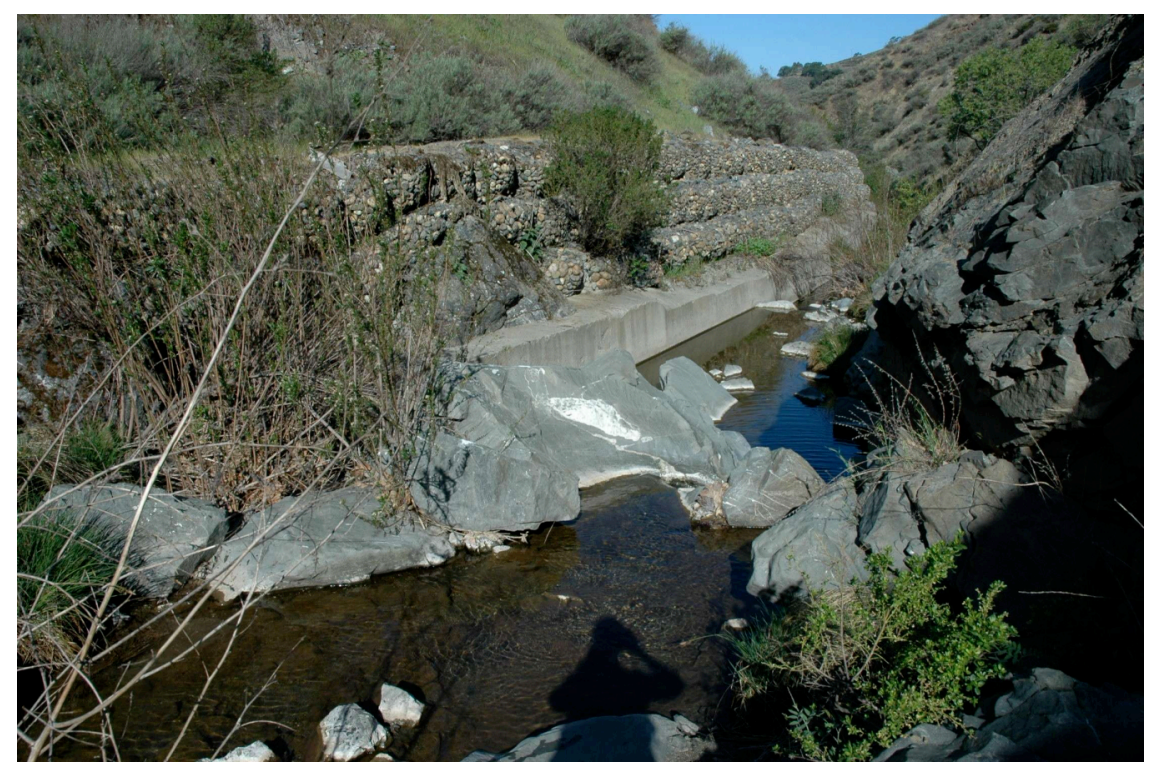

Photo 6. The gabion wall and concrete footing, as shown, protects the toe of the slope supporting the pump station. 